\title{
PERANAN KEPALA SEKOLAH DALAM IMPLEMENTASI SISTEM INFORMASI MANAJEMEN DI SEKOLAH
}

\author{
Oleh: \\ Oktaviani \\ Jurusan Administrasi Pendidikan Fakultas Ilmu Pendidikan Universitas Negeri \\ Padang, Padang, Indonesia \\ Email: oktaviani111999@gmail.com
}

\begin{abstract}
ABSTRAK
Indonesia di era kecanggihan teknologi perlu adanya suatu pengelolaan infomasi berbasis komputer atau aplikasi. Maka penting adanya implementasi sistem informasi manajemen terutama di dunia pendidikan. Peran kepala sekolah menjadi hal penting dalam implementasi sistem informasi manajemen di sekolah.
\end{abstract}

Kata Kunci : Sistem Informasi Manajemen, Peran Kepala Sekolah.

\begin{abstract}
Indonesia in the era of technological sophistication needs to have a computer-based or application-based information management. So it is important the implementation of management information systems, especially in the world of education. The role of the principal becomes important in the implementation of management information systems in schools.
\end{abstract}

Keywords : Management Information systems, The Role of The Principal.

\section{PENDAHULUAN}

Di era globalisasi pengelolaan informasi merupakan hal yang sangat penting dan dibutuhkan oleh setiap lembaga, baik lembaga sosial, politik, ekonomi, dan juga pendidikan. Didasari oleh PP RI No. 11 Tahun 2008 tentang informasi dan transaksi elektronik dinyatakan bahwa pembangunan nasional adalah suatu proses yang berkelanjutan yang harus senantiasa tanggap terhadap berbagai dinamika yang terjadi di masyarakat, bahwa globalisasi informasi telah menempatkan Indonesia sebagai bagain dari masyarakat informasi dunia sehingga mengharuskan dibentuknya pengaturan mengenai pengelolaan informasi dan transaksi elektronik di tingkat nasional sehingga pembangunan teknologi informasi dapat dilakukan secara optimal, merata, dan menyebar ke seluruh lapisan masyarakat guna mencerdaskan kehidupan 
bangsa. Perlu diketahui bahwa jaringan terluas dan terbesar yang digunakan ialah internet. Internet menjadikan alasan sistem informasi memainkan peran penting dan berpengaruh dalam organisasi. dalam organisasi pendidikan atau disebut sekolah perlu peran kepala sekolah dalam pengimplementasian sistem informasi manajemen di sekolah tersebut. Peran penting kepala sekolah ini perlu diperhatikan guna kemajuan sekolah tersebut dan perbaikan pendidikan dengan mengikuti perkembangan zaman. Saat ini Indonesia berada di era revolusi Industri 4.0, semua hal berujung pembicaraan pada suatu penggunaan teknologi. Maka sangat dipungkiri tidak bias tidak suatu sekolah menolak penggunaan sistem informasi manajemen di sekolahnya.

\section{KAJIAN PUSTAKA}

\section{Pengertian Sistem Informasi Manajemen}

Sistem merupakan satu kesatuan yang saling terkait. Informasi adalah data yang telah dikelola menjadi sebuah bentuk yang dapat diterima penerima sebagai pengetahuan. Manajemen adalah serangkaian kegiatan dimulai dari perencanaan hingga evaluasi juga tindak lanjut yang dilakukan oleh dua orang atau lebih untuk mencapai tujuan yang telah ditetapkan sebelumnya secara efektif dan efisien.

Jadi dapat disimpulkan dari pengertian masing-masing kata tersebut diatas yaitu, sistem informasi manajemen adalah suatu sistem pengelolaan data dan informasi guna pengambilan keputusan pada kegiatan maanjemen di organisasi. Penjelasan diperkuat oleh Hartono (2013) sistem informasi manajemen adalah sebuah sistem terorganisasi dari sejumlah bagian atau komponen yang secara bersama - sama berfungsi atau bergerak menghasilkan informasi untuk digunakan (Jaffar \& Sabandi, 2019). Raymond Mc. Leod mengatakan Sistem informasi manajemen adalah suatu sistem berbasis yang membuat informasi tersedia bagi para pengguna yang memiliki kebutuhan serupa (Fitriyah, 2011). Sistem informasi manajemen pendidikan adalah suatu sistem yang dirancang untuk menyediakan dan mengambil keputusan pada kegiatan manajemen dimulai dari perencanaan, pengorganisasian, penggerakan, hingga pengendalian dalam lembaga pendidikan. 


\section{Tujuan Sistem Informasi Manajemen}

Tujuan sistem informasi manajemen ialah menciptakan kelancaran sumber informasi di lembaga terkait, lebih mudah dalam pengolahan data dan mendapati data pada sistem organisasi/ lembaga terkait, mengontrol kualitas guna peningkatan mutu lembaga terkait. Tujuan dari sistem informasi manajemen pendidikan yang dikemukakan oleh Eti Rohayati (2005) menyatakan yaitu menghasilkan informasi yang tepat waktu (timely) bagi manajemen tentang lingkungan eksternal dan operasi internal, mendorong dan mempercepat proses pengambilan keputusan baik pada saat perencanaan, pengorganisasian, penggerakkan, dan pengendalian (Fitriyah, 2011).

\section{Manfaat Sistem Informasi Manajemen}

Manfaat sistem informasi manajemen ialah mampu menyediakan informasi dengan cepat dan tepat, akurat, relevan, dan efisien digunakan oleh manajemen guna pengambilan kebutuhan strategis. Sistem informasi manajemen pendidikan mampu meningkatkan pelayanan pendidikan guna pencapaian pendidikan berkualitas menyonsong tujuan sustainable development goal's 2030 bidang pendidikan. Sistem informasi manajemen mampu menaungi semua masalah-masalah keterbatasan antara didesa ataupun dikota, bahkan keterbatasan-keterbatasan antar lembaga-lembaga pendidikan (Fitriyah, 2011).

\section{Implementasi Sistem Informasi Manajemen dalam Manajemen Sekolah}

Sistem Informasi Manajemen Akademik ialah segala macam hasil interaksi antara elemen di lingkungan akademik untuk menghasilkan informasi yang dijadikan landasan pengambilan keputusan, melaksanakan tindakan, baik oleh pelaku proses itu sendiri ataupun dari pihak luar sekolah. Implementasi sistem informasi manajemen akademik di tingkat SMK memiliki kelengkapan manajemen data seperti: manajemen tahun ajaran, data jenis pelanggaran siswa di sekolah, data ekstrakurikuler, data mata pelajaran, data jurusan, data guru, data siswa, data kelas atau rombongan belajar, data nilai ekstrakurikuler, data pelanggaran siswa, data absensi siswa dan data absensi guru (Agustiandra and Sabandi, 2019). Secara sederhana, semua sistem informasi memiliki tiga kegiatan utama, meliputi : menerima data sebagai masukan (input), 
kemudian data tersebut di proses dengan melakukan penghitungan, penggabungan unsur data, pemutakhiran akun, dan sebagainya, lalu terakhir didapatkanlah informasi sebagai keluaran (output). Input merupakan aktivitas utama dalam penerapan sistem informasi manajemen berbasis komputer, karena aktivitas input adalah proses memasukan data ke dalam sebuah sistem yang telah dirancang oleh organisasi dalam memanejemen data yang kemudian akan di proses untuk mendapatkan sebuah informasi yang berguna bagi organisasi (Agustiandra and Sabandi, 2019). Proses merupakan bagian yang melakukan perubahan atau transformasi dari masukan menjadi keluaran (output) yang berguna. Dalam pemanfaatan informasi (output) yang dihasilkan oleh Sistem informasi maanjemen Akademik sekolah, sebaiknya ada beberapa kriteria informasi yang harus diperhatikan oleh guru, yaitu: (1) kepadatan informasi, (2) relevan, (3) akurat dan (4) kejelasan (Agustiandra and Sabandi, 2019).

Implementasi sistem informasi manajemen di sekolah kebanyakan terhambat pada pemasangan wireless jaringan wi-fi yang hanya terdapat dibeberapa sudut saja, kurang cakapnya pemakai sistem informasi manajemen tersebut terkhusus di sekolah yaitunya guru dan sulitnya penggunaan komputer oleh guru itu. Jadi, masalah nya terletak pada jaringan/internet serta sumber daya manusia.

\section{PEMBAHASAN}

Sistem informasi manajemen untuk sekolah merupakan seperangkat sistem informasi berbasiskan web terintegrasi yang terdiri dari empat portal utama, yaitu: (1) staff desk sebagai portal yang digunakan oleh guru dan pegawai sekolah untuk mengakses berbagai informasi yang dibutuhkan terkait kegiatan akademik; (2) student desk sebagai portal informasi bagi para siswa aktif di sekolah untuk mengakses informasi yang diperlukan; (3) parent desk sebagai portal informasi bagi orang tua/wali murid untuk mengakses informasi terkait dengan perkembangan anak di sekolah; (4) alumni desk sebagai portal informasi untuk menjalin komunitas dengan para alumni sekolah (Kurniawan, 2013).

Sistem informasi manajemen yang dikembangkan di lingkungan pendidikan disesuaikan dengan analisis kebutuhan dan perencanaan program sekolah 
(Darmawan, 2011). Perlu diterapkannya disiplin ilmu sistem informasi manajemen yang menjadikan setiap informasi yang didapat dikelola dengan baik sehingga output yang dihasilkan dapat dijadikan sebagi bahan pertimbangan untuk melakukan evaluasi terhadap setiap proses maupun aktivitas yang dilakukan di sekolah. Menurut Sabandi (2013) dengan pemanfaatan ilmu pengetahuan, dan teknologi yang semakin berkembang dapat meningkatkan kualitas pembelajaran (Agustiandra and Sabandi, 2019).

Berikut akan dibahas mengenai peran kepala sekolah dalam implementasi sistem informasi manajemen akademik di sekolah. Kepala sekolah perlu meningkatkan beberapa aspek mengenai:

1. Pengadaan sosialisasi bagi guru tentang tata cara penggunaan sistem informasi manajemen akademik sekolahnya, sehingga setiap guru memahami setiap langkah yang harus dikerjakannya. Sesuai pembahasan sebelumnya di kajian teori menyatakan bahwa sumber daya manusia merupakan salah satu faktor utama penghambat implementasi sistem informasi manajemen, maka perlu dengan tegas pengadaan sosialisasi bagi pemakai sistem informasi manajemen terkhusus guru jika disuatu sekolah.

2. Memberikan fitur/ tampilan sistem informasi manajemen akademik sekolahnya yang menarik, jelas dan sederhana, sehingga guru mampu dengan mudah melakukan input serta mendapatkan output dari sistem informasi manajemen akademik sekolah tersebut tanpa mengalami kesulitan karna fitur yang ada dirasa tidak terlalu sulit dipahami si pemakai atau guru sekolah tersebut. Namun, juga perlu adanya pembaharuan setiap saatnya agar tetap terlihat menarik dan baru.

3. Jaringan wi-fi yang memadai, dengan penempatannya di tempat-tempat penting dan terjangkau pada semua sudut tempat yang ada, sehingga membantu guru dalam mengakses. Jadi, diharapkan guru dapat dengan mudah melakukan input data absensi siswa setiap hari tanpa harus menunda-nunda proses menghimpun data yang bisa dilakukan setiap harinya.

Disamping itu perlu juga peran pengawas guna memberikan saran dan pembinaan kepada kepala sekolah dan guru-guru agar dapat memanfaatkan penerapan 
sistem informasi manajemen yang telah dirancang sekolah sebaik mungkin dan dapat melakukan pengembangan terhadap bidang yang belum menerapkan ssitem informasi manajemen berbasis komputer ataupun apliaksi.

\section{PENUTUP}

\section{Simpulan}

Implementasi sistem informasi manajemen di sekolah ada karena juga terdapatnya dukungan peran kepala sekolah dalam mengiplementasikan disekolahnya guna mengikuti kemajuan zaman. Di era kecanggihan teknologi saat ini tak luput tak dapat dipisahkan penggunaan teknologi terutama penerapan sistem informasi manajemen di sekolah dalam rangka memudahkan aktivitas pengolahan data di sekolah.

\section{Saran}

Implementasi suatu sistem informasi manajemen ini diharapkan sekolah dapat memperoleh manfaat terwujudnya suatu pusat informasi yang dapat diakses oleh siswa, guru maupun orangtua/wali siswa untuk memperoleh data-data pendidikan yang terkait dengan kewenangannya. Diharapkan kepala sekolah berperan aktif dalam implementasi sistem informasi manajemen di sekolahnya.

\section{DAFTAR PUSTAKA}

Agustiandra, V. and Sabandi, Ahmad. (2019) 'Persepsi Guru Terhadap Penerapan Sistem Informasi Manajemen Akademik Di Sekolah Menengah Kejuruan (SMK) Negeri 3 Padang', Jurnal Bahana Manajemen Pendidikan, 8(I), pp. 1-8. Available at: http://ejournal.unp.ac.id/index.php/bahana/article/view/103704.

Darmawan, D. (2011) 'Sim Berbasis Ict Dalam Mengembangkan Digital Library', Edulib, 1(1), pp. 87-100. doi: 10.17509/edulib.v1i1.1145.

Jaffar, Muhammad \& Sabandi, Ahmad. (2019) ‘金 薇 1, 2 宫长宝 1, 2’, 2019(2157), pp. 1-57. doi: 10.11693/hyhz20181000233.

Kurniawan, Y. (2013) 'Model Sistem Informasi Manajemen Sekolah Berbasiskan Notasi Unified Modeling Language', ComTech: Computer, Mathematics and Engineering Applications, 4(2), p. 1128. doi: 10.21512/comtech.v4i2.2572.

Fitriyah, Fifi. 'Penerapan sistem informasi manajemen pendidikan dalam 
meningkatkan pelayanan sekolah terhadap masyarakat pada website sma bakti mulya 400 skripsi' (2011). 